\title{
Point sampling for leaf area index in sagebrush steppe communities
}

\author{
PATRICK E. CLARK AND MARK S. SEYFRIED
}

Authors are range scientist and soil scientist, USDA Agricultural Research Service, 800 Park Blvd., Plaza IV, Suite 105, Boise, Ida. 83712.

\begin{abstract}
Although point sampling has been used for more than 30 years to quantify leaf area index (LAI), this field technique has not been rigorously evaluated in sagebrush steppe plant communities. Leaf area index estimates obtained using different sampling pin inclinations or combinations of pin inclinations were evaluated in Wyoming big sagebrush (Artemisia tridentata Nutt. ssp. wyomingensis Beetle and Young), low sagebrush (Artemisia arbuscula Nutt.), and mountain big sagebrush (Artemisia tridentata Nutt. ssp. vaseyana [Rydb.] Beetle) communities within the Reynolds Creek Experimental Watershed near Boise, Ida. Leaf area index values determined by clipping and processing green foliage through a leaf area meter were used as evaluation standards. Pins inclined at $13^{\circ}$ from the horizontal, used alone or in combination with pins of $52^{\circ}$ and/or $90^{\circ}$ inclinations, performed poorly for estimating LAI in the Wyoming big sagebrush and low sagebrush communities. Estimating total LAI with either the combination of $52^{\circ}$ and $90^{\circ}$ angle pins or with $52^{\circ}$ or $90^{\circ}$ pins alone explained at least $96 \%$ of the variability in LAI standard values from the Wyoming big sagebrush and mountain big sagebrush communities. Using $52^{\circ}$ angle pins alone produced model fits similar to those obtained when the combination of $52^{\circ}$ and $90^{\circ}$ angle pins were used to estimate shrub, graminoid, and forb LAI across all 3 communities $(P>0.1)$. Collecting point data using $52^{\circ}$ angle pins often provided better or similar model fits with LAI standards compared to other pin angles but using $90^{\circ}$ angle pins offers a better compromise between practicality, efficiency, and accuracy.
\end{abstract}

Key Words: Artemisia arbuscula, Artemisia tridentata ssp. vaseyana, Artemisia tridentata ssp. wyomingensis, LAI, low sagebrush, mountain big sagebrush, Wyoming big sagebrush

Point sampling has been one of the most commonly used field techniques for quantifying leaf area index (LAI) in rangelands (Bonham 1989). This technique involves pushing a sharpened pin through the vegetation canopy and recording the number of pinpoint contacts with green foliage. Leaf area index (expressed as units of green foliage surface area per unit of ground surface area) is determined by dividing the number of foliage contacts by the total number of pins used in a given area.

This research was funded by the USDA Agricultural Research Service. Authors wish to thank C. Bonham, C. Hanson, and 3 anonymous reviewers for their critical review and comments on drafts of this manuscript.

Manuscript accepted 22 Oct. 00.

\section{Resumen}

Aunque el muestreo de puntos ha sido utilizado por más de 30 años para cuantificar el índice de área foliar (IAF), esta técnica de campo no ha sido evaluada rigurosamente en las comunidades esteparias de "Sagebrush". Se evaluaron estimaciones del índice de área foliar obtenidas con diferentes grados de inclinación de los alfileres o combinaciones de inclinaciones en comunidades de "Wyoming big sagebrush" (Artemisia tridentata Nutt. ssp. wyomingensis Beetle and Young), "Low sagebrush" (Artemisia arbuscula Nutt.) y "Mountain big sagebrush" (Artemisia tridentata Nutt. ssp. vascyana [Rydb.] Beetle) dentro de la Cuenca Hidrológica Experimental Reynolds Creek cerca de Boise, Idaho. Los valores del IAF determinados en forraje verde cortado y con el uso de un medidor de área foliar se utilizaron como estándares de evaluación. Los alfileres inclinados a 13 grados del plano horizontal, utilizados solos o en combinación con alfileres a 52 y/o 90 grados de inclinación, estimaron pobremente el IAF de las comunidades de "Wyoming big sagebrush" and "Low sagebrush". La estimación del IAF total tanto con la combinación de 52 y 90 grados de ángulo de inclinación de los alfileres o con los alfileres solos a inclinados a 52 y 90 grados explicaron al menos el $96 \%$ de la variabilidad de los valores estándar del IAF de las comunidades de "Wyoming big sagebrush" and "Mountain big sagebrush". Usando alfileres con una sola inclinación de 52 grados se produjeron modelos que concuerdan con los obtenidos con la combinación 52 y 90 grados de inclinación para estimar el IAF de arbustos, hierbas y gramíneas a través de las 3 comunidades ( $P$ > 0.1). En comparación con otros angulos de inclinacion de los alfileres, el colectar datos de punto utilizando un ángulo de inclinación de los alfileres de 52 grados a menudo provee mejores modelos o similares a los del IAF estándar, pero uso la inclinación de 90 grados ofrece un mejor balance entre lo práctico, la eficiencia y la certeza.

Other field techniques for quantifying LAI are based on light interception or destructive sampling. Where LAI is relatively low, as in the sagebrush steppe, light interception techniques overestimate LAI of woody plants because light intercepted by foliage cannot be differentiated from light intercepted by woody stems and branches (Barclay 2000). Harvesting and processing foliage through an electronic leaf area meter is the most accurate means of quantifying LAI (Beerling and Fry 1990). There are several advantages, however, in using point sampling over a leaf area meter for determination of LAI. Point sampling facilitates: 1) repeated measurement of LAI at the same sampling point over time, 2) rapid sample collection, and 3) determination of both leaf area and spatial arrangement of foliage (Warren Wilson 1963, Philip 1965). 
Typically, vertical pins $\left(90^{\circ}\right.$ inclination) are used in point sampling, however, pins inclined at a shallower angle may provide more accurate estimates of leaf area index (Warren Wilson 1959, 1960, 1963). Vertical pins may underestimate LAI of grasses and other plants with erect leaves and overestimate LAI of plants with predominately horizontal leaves. Warren Wilson (1963) suggested the maximum error of point LAI estimates could be reduced to about $7 \%$ by using pins inclined at $32.5^{\circ}$ from horizontal. Using 2 pin angles, specifically $13^{\circ}$ and $52^{\circ}$, should further reduce the maximum error to $2.5 \%$.

Although point sampling has be used for more than 30 years to quantify LAI, the technique has not been rigorously evaluated in sagebrush steppe plant communities. The objectives of this study were to evaluate different pin angles of the point sampling technique for characterizing total, shrub, graminoid, and forb LAI in 3 different sagebrush (Artemisia spp. Nutt.) communities.

\section{Materials and Methods}

\section{Study Area}

The study was conducted in the Reynolds Creek Experimental Watershed (RCEW) located $80 \mathrm{~km}$ south of Boise in southwestern Idaho $\left(43^{\circ} 11^{\prime} \mathrm{N}, 116^{\circ} 46^{\prime}\right.$ $\mathrm{W})$. The RCEW is $234 \mathrm{~km}^{2}$ in area and ranges in elevation from 1,097 to $2,252 \mathrm{~m}$. Mean annual precipitation ranges from $240 \mathrm{~mm}$ at lower elevations to $1,130 \mathrm{~mm}$ at higher elevations (Hanson et al. 1980). About $75 \%$ of the precipitation in the higher elevations falls as snow (Cooley et al. 1988). Summers are very dry throughout the watershed.

Soils of the experimental watershed are derived primarily from 4 parent materials, basalt $(63 \%$ of the watershed), granite (18\%), alluvium/lacustrine sediments (12\%), and welded tuff (6\%) (Stephenson 1977). Aridisols dominate the lowest elevations and Mollisols are most common elsewhere. Soils derived from granite are generally in coarse-loamy families and the others are generally in fine-loamy families. Excluding valley bottoms and snow drift areas, soils are shallow and rocky with steep topography.

Three sagebrush communities evaluated in this study were: 1) Wyoming big sagebrush (Artemisia tridentata Nutt. ssp. wyomingensis Beetle and Young), 2) low sagebrush (Artemisia arbuscula Nutt.), and 3) mountain big sagebrush (Artemisia tridentata Nutt. ssp. vaseyana [Rydb.] Beetle). A detailed characterization of the flora in the Reynolds Creek watershed has been conducted by Spaeth et al. (2000). The Wyoming big sagebrush community dominates at the lower elevations $(<1,400$ $\mathrm{m})$ of the watershed. Principal species are Wyoming big sagebrush, bluebunch wheatgrass (Agropyron spicatum [Pursh] Scribn. \& Smith), and Sandberg bluegrass (Poa secunda J. Presl.). The low sagebrush community occurs at the mid-elevations $(1,400$ to $1,600 \mathrm{~m})$. Low sagebrush, Sandberg bluegrass, and arcane milkvetch (Astragalus obscurus S. Wats.) are the principal species in this community. The mountain big sagebrush community dominates at the higher elevations $(>1,600 \mathrm{~m})$. The principal species include mountain big sagebrush, mountain snowberry (Symphoricarpos oreophilus Gray), mountain brome (Bromus marginatus Nees ex Steud.), elk sedge (Carex geyeri Boott), lupine (Lupinus spp. L), and sticky cinquefoil (Potentilla glandulosa Lindl.).

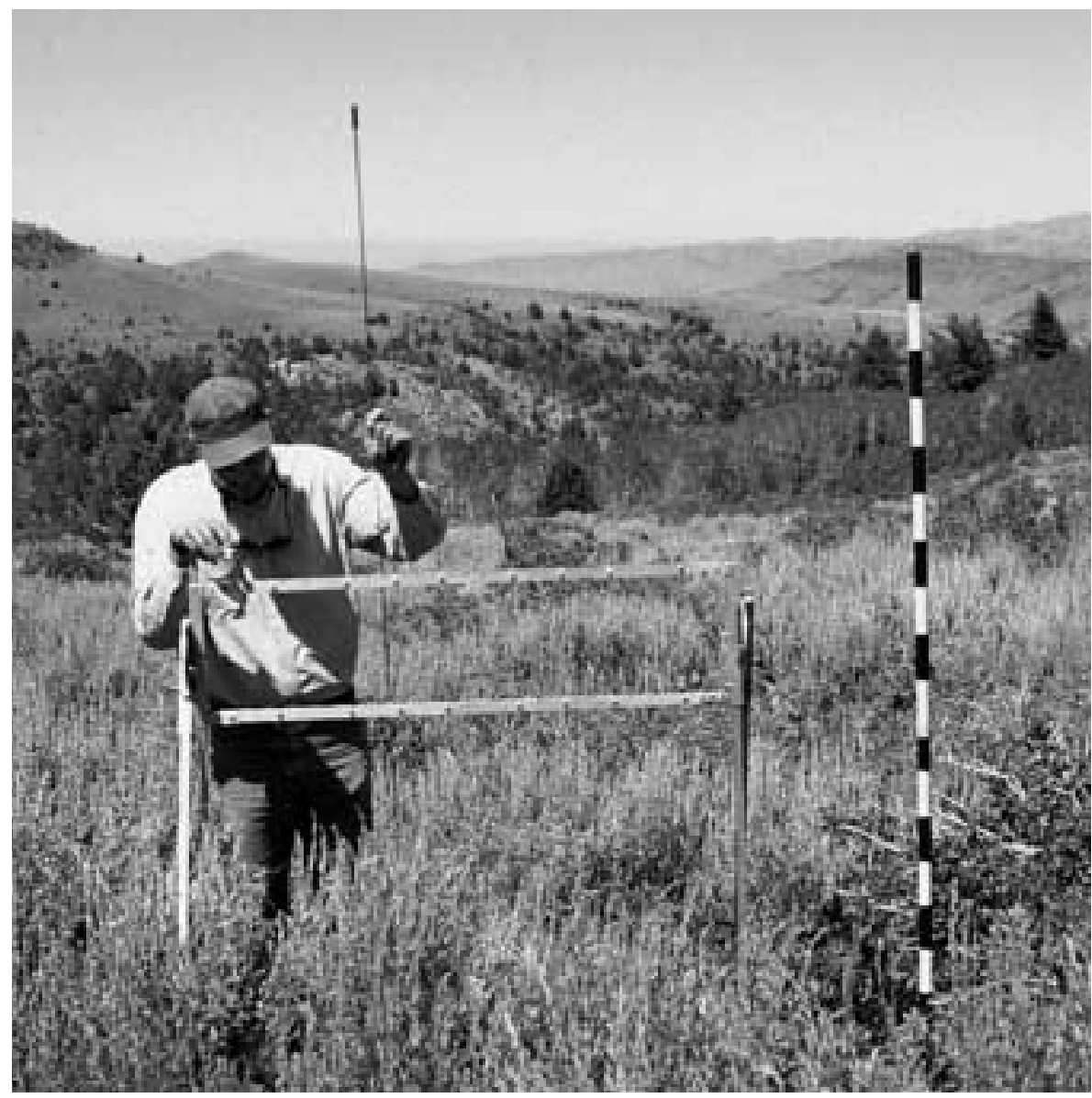

Fig. 1. Sampling LAI in the mountain big sagebrush community at the Reynolds Creek Experimental Watershed near Boise, Ida. using a 20-pin frame adjusted to sample points with sharpened pins inclined $90^{\circ}$ to the horizontal.

\section{Sampling Procedures}

Point data were collected along four or five, 30-m transects randomly located within each of the 3 sagebrush communities. Each transect was aligned north-south and contained 6 randomly selected sampling locations. A $1-\mathrm{m}^{2}$, square frame marked at $10-\mathrm{cm}$ intervals was centered over each sampling location along a transect, forming the perimeter of the LAI sampling space for that location. A 20-pin point frame with $5-\mathrm{cm}$ pin spacings, magnetic pin brakes, bubble levels, and 4 adjustable legs was straddled over the 1$\mathrm{m}^{2}$ frame to collect point data (Fig. 1). Although point sampling using pins grouped on a point frame is statistically less efficient than using a single, individually placed pin (Goodall 1952), point sampling to characterize LAI is most commonly done using point frames (GreigSmith 1983). At each sampling location within the Wyoming big sagebrush and low sagebrush communities, point data were collected at 3 different pin inclination angles from the horizontal: 1)13 ${ }^{\circ}, 2$ ) 
$52^{\circ}$, and 3) $90^{\circ}$. Point data from the mountain big sagebrush community were collected using only the $52^{\circ}$ and $90^{\circ}$ inclinations because dense vegetation cover restricted accurate sampling at the $13^{\circ}$ inclination.

The $90^{\circ}$ point data for each sampling location were collected by positioning, leveling, and reading the point frame at 4 stations spaced at $20-\mathrm{cm}$ intervals within the $1-\mathrm{m}^{2}$ frame (Fig. 1). Each of the 20 pins was pushed vertically through the plant canopy to the ground surface. All pin-point contacts with green foliage were counted, classified as either shrub, graminoid, or forb, and recorded.

The $13^{\circ}$ and $52^{\circ}$ point data were collected by positioning the point frame over the $1-\mathrm{m}^{2}$ frame, inclining the point frame to the appropriate angle, aligning the lower cross member of the point frame directly over and parallel to the edge of the $1-\mathrm{m}^{2}$ frame, and reading each pin. Contacts with green foliage were recorded as the pins passed from the near edge of the $1-\mathrm{m}^{2}$ frame, through the sampling space, and finally touched the ground surface at the opposite edge of the $1-\mathrm{m}^{2}$ frame. This procedure was repeated for all 4 cardinal directions at each sampling location.

This design allowed sampling of 80 points from each of the $90^{\circ}, 52^{\circ}$, and $13^{\circ}$ pin inclination angles from a sampling space of approximately $1 \mathrm{~m}^{3}$ at each of the 6 locations on a transect. Transects were treated as experimental units. Point estimates of LAI were based on transect means calculated by dividing the number of contacts per transect by 480 pins per transect.

The precision and accuracy of point estimates of LAI were compared to LAI standard values determined using clipped samples and a leaf area meter. At each sampling location following completion of point sampling, ten, $1-\mathrm{dm}^{2}$ square frames were randomly located within the larger 1$\mathrm{m}^{2}$ frame. All green foliage within the vertical projection of these 10 frames was clipped, sorted, and pooled forming 1 composite sample for each of the shrub, graminoid, and forb growth forms per sampling location. To avoid leaf shrinkage and rolling, samples were stored in sealed plastic bags, refrigerated, and processed within 72 hours of harvest. Leaf area of the samples was determined using a LAI3000 Leaf Area Meter ( ${ }^{1} \mathrm{Li}-\mathrm{Cor}$, Inc., Lincoln, Nebraska) which was calibrated between runs using a standard $10-\mathrm{cm}^{2}$

\footnotetext{
${ }^{1}$ Mention of manufactures or trade names is for the convenience of the reader only and implies no endorsement on the part of the authors or USDA.
}

Table 1. Observed range in total leaf area index (LAI) and percent contributions of shrub, graminoid, and forb growth forms to total LAI of Wyoming big sagebrush, low sagebrush, and mountain big sagebrush communities at the Reynolds Creek Experimental Watershed near Boise, Ida.

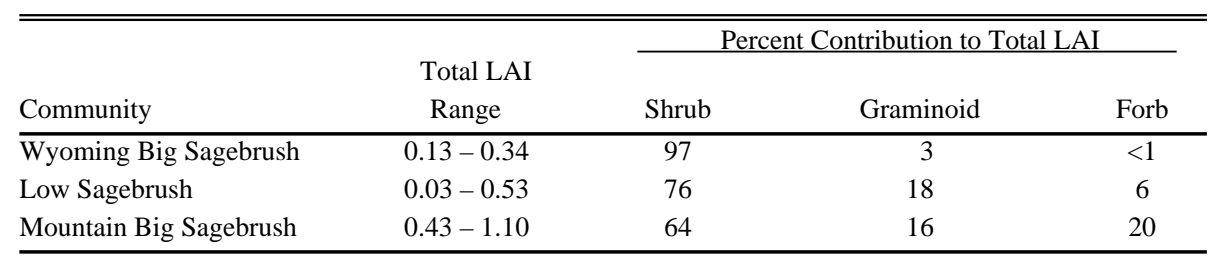

metal disk. Note that the LAI standard values described above were estimates rather than true measurements of LAI within the 1- $\mathrm{m}^{3}$ sampling space. True measurement of LAI required clipping all the green foliage from the entire sample space and processing this perishable material before it began to shrink and deform. Labor and equipment constraints prevented measurement of true LAI in this study.

\section{Statistical Analyses}

The General Linear Model (GLM) procedure (SAS 1988) was used to evaluate relationships between LAI values derived from point data and LAI standard values obtained with the LAI meter in the 3 different plant communities from the shrub, graminoid, and forb growth forms. Two data sets were used in these analyses. One data set contained point data from all 3 pin angles used in the Wyoming big sagebrush and low sagebrush communities only. A step-wise regression analysis was applied to this data set to evaluate the relative contribution of $13^{\circ}$ angle point data for estimating total LAI and shrub LAI for these 2 plant communities combined. Tests for statistical differences in the fits of the full and reduced GLM models were evaluated using extra sum of squares F-tests (Ramsey and Schafer 1997). Models with the same number of parameters (such as $13^{\circ}$ vs. $52^{\circ}$ angle) were compared using the adjusted coefficient of determination (adjusted $\mathrm{R}^{2}$ ), root mean square error (RMSE), and slope estimates as criteria. Graminoid and forb cover were too sparse in the Wyoming big sagebrush and low sagebrush communities for an adequate evaluation of LAI.

The second data set included $52^{\circ}$ and $90^{\circ}$ angle point data from all 3 sagebrush communities. A step-wise regression analysis was also used to evaluate point data collected using these pin angles for estimating total, shrub, graminoid, and forb LAI for all 3 plant communities combined and of total LAI for each individual plant community. Most of the data subsets used for estimating LAI by growth form within each community exhibited highly skewed distributions preventing robust tests. Consequently, only the performance of $52^{\circ}$ and $90^{\circ}$ angle point data for estimating shrub and forb LAI in the mountain big sagebrush community were evaluated. Extra sum of squares F-tests were used to compare fits between full and reduced models and the adjusted $R^{2}$, RMSE, and slope estimates were used to compare models with the same number of parameters.

\section{Results and Discussion}

\section{Range of Observed LAI}

Observed total LAI values in the 3 sagebrush communities evaluated in this study were similar to those observed on the short grass steppe of Colorado (maximum LAI $=0.5$, Lapitan and Parton 1996) and relatively low compared to the prairie grasslands of Kansas (maximum LAI 3.2, Welles and Norman 1991) (Table 1). Shrubs were the primary contributor to total LAI in these sagebrush communities. Graminoids made substantial contributions, however, to total LAI of the low sagebrush and mountain big sagebrush communities. Forbs made a notable LAI contribution only in the mountain big sagebrush community.

\section{LAI Estimation with $13^{\circ}$ Angle Pins}

Point data from $13^{\circ}$ angle pins inadequately estimated total LAI in the Wyoming big sagebrush and low sagebrush communities combined. Regressing $13^{\circ}$ angle data against total LAI standard values produced much lower adjusted $\mathrm{R}^{2}$ values than when $52^{\circ}$ or $90^{\circ}$ angle data were used (Table 2). When $13^{\circ}$ angle data were combined with $52^{\circ}$ and/or $90^{\circ}$ angle data, inclusion of the $13^{\circ}$ angle data had no effect on model fit $(\mathrm{P}>0.1)$ except in 1 case. Using the $13^{\circ}$ and $52^{\circ}$ angle data combination did improve model fit over 
Table 2. Comparison of regression fit statistics revealing the contribution of point data collected using $13^{\circ}, 52^{\circ}$, and $/$ or $90^{\circ}$ angle pins for estimating total and shrub leaf area index (LAI) in the combined Wyoming big sagebrush and low sagebrush communities at the Reynolds Creek Experimental Watershed near Boise, Ida.

\begin{tabular}{|c|c|c|}
\hline Regression Models $^{1}$ & Adjusted $\mathrm{R}^{2}$ & RMSE $^{2}$ \\
\hline \multicolumn{3}{|l|}{ Total } \\
\hline $\mathrm{LAI}=-0.0019+0.035(\mathrm{~L})+0.33(\mathrm{H})+0.74(\mathrm{~V})$ & 0.935 & 0.0243 \\
\hline $\mathrm{LAI}=-0.00080+0.26(\mathrm{H})+0.91(\mathrm{~V})$ & 0.935 & 0.0242 \\
\hline $\mathrm{LAI}=-0.0021+0.11(\mathrm{~L})+0.77(\mathrm{H})$ & 0.917 & 0.0274 \\
\hline $\mathrm{LAI}=0.0044+0.90(\mathrm{H})$ & 0.882 & 0.0326 \\
\hline $\mathrm{LAI}=-0.00072-0.0033(\mathrm{~L})+1.2(\mathrm{~V})$ & 0.927 & 0.0257 \\
\hline $\mathrm{LAI}=-0.00083+1.2(\mathrm{~V})$ & 0.930 & 0.0252 \\
\hline $\mathrm{LAI}=0.017+0.33(\mathrm{~L})$ & 0.507 & 0.0668 \\
\hline \multicolumn{3}{|l|}{ Shrub } \\
\hline $\mathrm{LAI}=0.015-0.061(\mathrm{~L})+0.62(\mathrm{H})+0.37(\mathrm{~V})$ & 0.856 & 0.0357 \\
\hline $\mathrm{LAI}=0.0011+0.59(\mathrm{H})+0.38(\mathrm{~V})$ & 0.868 & 0.0341 \\
\hline $\mathrm{LAI}=0.022-0.063(\mathrm{~L})+0.84(\mathrm{H})$ & 0.868 & 0.0342 \\
\hline $\mathrm{LAI}=0.0080+0.82(\mathrm{H})$ & 0.876 & 0.0331 \\
\hline $\mathrm{LAI}=0.0076-0.046(\mathrm{~L})+1.2(\mathrm{~V})$ & 0.800 & 0.0420 \\
\hline $\mathrm{LAI}=-0.0023+1.2(\mathrm{~V})$ & 0.823 & 0.0395 \\
\hline $\mathrm{LAI}=0.13+0.069(\mathrm{~L})$ & -0.129 & 0.0998 \\
\hline
\end{tabular}

${ }^{1}$ Regression models where, $\mathrm{L}=13^{\circ}$ angle pins, $\mathrm{H}=52^{\circ}$ angle pins, and $\mathrm{V}=90^{\circ}$ angle pins.

${ }^{2} \mathrm{RMSE}=$ Root mean square error.

using the $52^{\circ}$ angle data alone for estimating total LAI $(\mathrm{P}<0.01)$.

In all cases, inclusion of $13^{\circ}$ angle data in combination with $52^{\circ}$ and/or $90^{\circ}$ angle data did not affect model fit for estimating shrub LAI for the Wyoming big sagebrush and low sagebrush communities combined $(\mathrm{P}>0.1)$ (Table 2). Additionally, there was no linear relationship between shrub LAI values estimated with $13^{\circ}$ angle data alone and shrub LAI standard values.

The $13^{\circ}$ inclination angle performed poorly for LAI estimation in these 2 sagebrush communities because of difficulties in sampling shrub LAI. The canopy of Wyoming big sagebrush and low sagebrush was typically elevated on a central trunk where pins inclined at $13^{\circ}$ frequently passed under the sagebrush canopy. Only sagebrush canopy occupying the near side of the plot (where the pin first entered the plot) was sampled. Even when $13^{\circ}$ angle pins were inserted from all 4 sides of the plot, sagebrush canopy in the plot center and elevated more than $15 \mathrm{~cm}$ was excluded from the sample. Since shrubs contribute most of the leaf area in Wyoming big sagebrush and low sagebrush communities (Table 1), this sampling bias produced large errors in both the shrub and total LAI estimates. Sampling several different layers of the vegetation canopy by elevating the entire point frame in a series of steps may have helped alleviate this sampling bias when $13^{\circ}$ angle pins were used. Frame positioning and sampling using $13^{\circ}$ angle pins in the rigid, woody canopy of these sagebrush communities was awkward and physically difficult. Consequently, improvements in LAI estimation obtained by increasing sampling
Total LAI and LAI by Growth Form for All Communities Combined

Combining $52^{\circ}$ and $90^{\circ}$ angle data to estimate total LAI for all 3 sagebrush communities combined resulted in a better model fit than using either $52^{\circ}(\mathrm{P}<0.001)$ or $90^{\circ}(\mathrm{P}<0.001)$ angle data alone (Table 3). All 3 models, however, explained more than $95 \%$ of the variability in total LAI standard values for these 3 communities.

Estimating shrub LAI for the combination of these 3 communities using either the $52^{\circ}$ and $90^{\circ}$ angle data combination or $52^{\circ}$ angle data alone produced similar model fits $(\mathrm{P}>0.1)$ with both models explaining more than $97 \%$ of the variability in shrub LAI (Table 3). Estimating shrub LAI using $90^{\circ}$ angle data alone resulted in a poorer model fit than using the $52^{\circ}$ and $90^{\circ}$ angle data combination $(\mathrm{P}$ $<0.05)$.

Regression models based on either the combination of $52^{\circ}$ and $90^{\circ}$ angle data or $90^{\circ}$ angle data alone had similar fits $(\mathrm{P}>$ 0.1 ) and explained more than $96 \%$ of the variability in graminoid LAI standard values (Table 3). Estimating graminoid LAI using $52^{\circ}$ angle data alone resulted in a poorer model fit than the combination of $52^{\circ}$ and $90^{\circ}$ angle data $(\mathrm{P}<0.001)$. A single outlier, representing data from a low sagebrush site located on a north slope with relatively high Idaho fescue (Festuca idahoensis Elmer) cover, was linked to this poor fit. With this outlier removed,

Table 3. Comparison of regression fit statistics revealing the contribution of point data collected using $52^{\circ}$ and/or $90^{\circ}$ angle pins for estimating total, shrub, graminoid, and forb leaf area index (LAI) in the combined Wyoming big sagebrush, low sagebrush, and mountain big sagebrush communities at the Reynolds Creek Experimental Watershed near Boise, Ida.

\begin{tabular}{lll}
\hline \hline Regression Models ${ }^{1}$ & Adjusted $\mathrm{R}^{2}$ & RMSE $^{2}$ \\
\hline Total & & 0.0231 \\
LAI $=0.0028+0.44(\mathrm{H})+0.57(\mathrm{~V})$ & 0.973 & 0.0284 \\
LAI $=0.0061+0.86(\mathrm{H})$ & 0.959 & 0.0284 \\
LAI $=0.0027+1.1(\mathrm{~V})$ & 0.959 & \\
$\quad$ Shrub & & 0.0270 \\
LAI $=0.0037+0.67(\mathrm{H})+0.23(\mathrm{~V})$ & 0.972 & 0.0269 \\
LAI $=0.0040+0.84(\mathrm{H})$ & 0.972 & 0.0389 \\
LAI $=0.011+1.1(\mathrm{~V})$ & 0.941 & \\
$\quad$ Graminoid & & 0.0147 \\
LAI $=-0.0055+0.038(\mathrm{H})+1.2(\mathrm{~V})$ & 0.965 & 0.0318 \\
LAI $=-0.0049+1.2(\mathrm{H})$ & 0.836 & 0.0141 \\
LAI $=-0.0052+1.2(\mathrm{~V})$ & 0.968 & 0.0099 \\
LAI $(\mathrm{R})^{3}=-0.00059+1.0(\mathrm{H})-0.16(\mathrm{~V})$ & 0.968 & 0.0096 \\
LAI $(\mathrm{R})=-0.0011+0.91(\mathrm{H})$ & 0.968 & 0.0143 \\
LAI $(\mathrm{R})=-0.0037+1.2(\mathrm{~V})$ & 0.930 & \\
Forb & & 0.0180 \\
LAI $=0.0015+0.92(\mathrm{H})+0.076(\mathrm{~V})$ & 0.960 & 0.0172 \\
LAI $=0.0011+1.0018(\mathrm{H})$ & 0.963 & 0.0222 \\
LAI $=0.0064+0.94(\mathrm{~V})$ & 0.939 &
\end{tabular}

${ }_{2}$ Regression models where, $\mathrm{H}=52^{\circ}$ angle pins and $\mathrm{V}=90^{\circ}$ angle pins.

${ }^{2} \mathrm{RMSE}=$ Root mean square error.

${ }^{3} \mathrm{LAI}(\mathrm{R})=$ outlier removed. 
estimating graminoid LAI using either the $52^{\circ}$ and $90^{\circ}$ angle data combination or $52^{\circ}$ angle data alone resulted in similar model fits $(\mathrm{P}>0.1)$ while using $90^{\circ}$ angle data alone resulted in a poorer model fit than the $52^{\circ}$ and $90^{\circ}$ angle data combination (P $<0.01)$. The cause of this outlier is difficult to explain but may be related to potential sampling error resulting from difficulty in observing point contacts within the dense clumps of fine, rolled leaves typical of Idaho fescue.

The model fit where the $52^{\circ}$ and $90^{\circ}$ angle data combination was regressed against forb LAI standard values was similar to that when either $52^{\circ}$ angle data alone $(\mathrm{P}>0.1)$ or $90^{\circ}$ angle data alone $(\mathrm{P}$ $>0.05$ ) were used (Table 3 ). All 3 models explained more than $93 \%$ of the variability in forb LAI.

\section{Total LAI and LAI by Growth Form Within Each Community}

Estimating total LAI in the Wyoming big sagebrush community using either the $52^{\circ}$ and $90^{\circ}$ angle data combination or $52^{\circ}$ or $90^{\circ}$ angle data alone resulted in similar model fits $(\mathrm{P}>0.05)$ (Table 4). All 3 models explained more than $96 \%$ of the variability in total LAI standard values.

The regression model based on the $52^{\circ}$ and $90^{\circ}$ angle data combination explained more than $84 \%$ of the variability in total LAI standard values from the low sagebrush community (Table 4). Estimating total LAI using the $90^{\circ}$ angle data alone was similar to using the $52^{\circ}$ and $90^{\circ}$ angle data combination $(\mathrm{P}>0.1)$ while using the $52^{\circ}$ angle data produced a poorer fit than the full model $(\mathrm{P}<0.025)$.

Estimating total LAI of the mountain big sagebrush community using the $52^{\circ}$ and $90^{\circ}$ angle data combination explained more than $99 \%$ of the variability in total LAI standard values (Table 4). Regression models based on only $52^{\circ}(\mathrm{P}<$ $0.01)$ or $90^{\circ}$ angle data $(\mathrm{P}<0.001)$ explained less of the variability in LAI standard values than the full model. Both of these reduced models, however, explained more than $96 \%$ of the variability in total LAI standard values. Although the adjusted $R^{2}$ and RMSE values in Table 4 suggest the $90^{\circ}$ angle data did not perform as well as the full model for shrub LAI estimation, model fits using either $52^{\circ}$ or $90^{\circ}$ angle data alone were statistically similar to those when the $52^{\circ}$ and $90^{\circ}$ angle data combination was used for estimating shrub $(\mathrm{P}>0.1)$ and forb $(\mathrm{P}>0.1)$ LAI in the mountain sagebrush community.

The regression models described above indicate point data collected with the $90^{\circ}$

Table 4. Comparison of regression fit statistics revealing the contribution of point data collected using $52^{\circ}$ and/or $90^{\circ}$ angle pins for estimating total leaf area index (LAI) in the Wyoming big sagebrush, low sagebrush, and mountain big sagebrush communities and shrub and forb LAI in the mountain big sagebrush community at the Reynolds Creek Experimental Watershed near Boise, Ida.

\begin{tabular}{lcc}
\hline \hline Regression Models $^{1}$ & Adjusted R & RMSE $^{2}$ \\
\hline Wyoming Big Sagebrush & & \\
Total LAI $=0.0011+0.43(\mathrm{H})+0.63(\mathrm{~V})$ & 0.972 & 0.0178 \\
Total LAI $=0.0058+0.85(\mathrm{H})$ & 0.964 & 0.0202 \\
Total LAI $=-0.0023+1.3(\mathrm{~V})$ & 0.964 & 0.0203 \\
$\quad$ Low Sagebrush & & 0.0330 \\
Total LAI $=-0.0020+0.24(\mathrm{H})+0.97(\mathrm{~V})$ & 0.843 & 0.0432 \\
Total LAI $=-0.0054+1.1(\mathrm{H})$ & 0.732 & 0.0322 \\
Total LAI $=0.0016+1.2(\mathrm{~V})$ & 0.851 & \\
$\quad$ Mountain Big Sagebrush & & 0.0152 \\
Total LAI $=0.0033+0.59(\mathrm{H})+0.34(\mathrm{~V})$ & 0.992 & 0.0196 \\
Total LAI $=0.0068+0.85(\mathrm{H})$ & 0.986 & 0.0333 \\
Total LAI $=0.0037+1.1(\mathrm{~V})$ & 0.961 & 0.0186 \\
Shrub LAI $=-0.012+0.80(\mathrm{H})+0.096(\mathrm{~V})$ & 0.986 & 0.0157 \\
Shrub LAI $=-0.015+0.88(\mathrm{H})$ & 0.990 & 0.0460 \\
Shrub LAI $=0.037+1.0(\mathrm{~V})$ & 0.913 & 0.0170 \\
Forb LAI $=-0.0051+0.54(\mathrm{H})+0.46(\mathrm{~V})$ & 0.978 & 0.0187 \\
Forb LAI $=-0.012+1.0(\mathrm{H})$ & 0.973 & 0.0191 \\
Forb LAI $=0.0048+0.93(\mathrm{~V})$ & 0.972 & \\
\hline
\end{tabular}

Regression models where, $\mathrm{H}=52^{\circ}$ angle pins and $\mathrm{V}=90^{\circ}$ angle pins

RMSE $=$ Root mean square error.

or $52^{\circ}$ angle pins require some correction to provide accurate estimates of LAI (Tables 3 and 4). Since the y-intercepts for each of these models did not differ from zero $(\mathrm{P}>0.50)$, multiplying the point data by the regression slope value can be used to provide the correction needed to approximate the LAI standard values.

\section{Summary and Conclusions}

The $13^{\circ}$ angle point sampling technique was difficult and impractical to apply in sagebrush communities and contained a sampling bias against shrubs. Elevating the point frame to avoid the bias by sampling multiple levels within the shrub canopy would make the technique even more difficult and impractical to apply.

Point data collected with $52^{\circ}$ and $90^{\circ}$ angle pins performed well for estimating LAI in the Wyoming big sagebrush, low sagebrush, and mountain big sagebrush communities. With only 2 exceptions, using the $52^{\circ}$ or $90^{\circ}$ angle data alone provided regression fits similar to that when the combination of $52^{\circ}$ and $90^{\circ}$ angle data were used (Tables 3 and 4). Even in these 2 exceptional cases (i.e., estimation of combined total LAI for all 3 communities and total LAI for the mountain big sagebrush community), improvements in the regression fit of the data obtained by applying a combination of pin angles did not offset the additional time and effort required to do so.
The $52^{\circ}$ angle data provided a somewhat higher adjusted $\mathrm{R}^{2}$ and lower RMSE value for modeling shrub LAI for the 3 community combination than did the $90^{\circ}$ angle data. The $52^{\circ}$ angle data performed as well as the $90^{\circ}$ angle data for estimating total and forb LAI in all communities combined and total LAI in the Wyoming big sagebrush community and shrub and forb LAI in the mountain big sagebrush community.

Given the above results, the $52^{\circ}$ angle might be considered as the technique of choice for LAI estimation in these sagebrush communities. In most cases, however, using either $52^{\circ} \mathrm{O}$ or $90^{\circ}$ angle data explained more than $90 \%$ of the variability in the LAI standard values which would be quite satisfactory for most applications requiring LAI. Additionally, there is a trade-off between efficiency and accuracy that must be considered. Because of the obstructiveness of sagebrush steppe vegetation, inclined pins required noticeably more time and effort to position and read than $90^{\circ}$ angle pins. Point sampling with $52^{\circ}$ angle pins required more time to thread and align the frame legs through rigid vegetation than when $90^{\circ}$ angle pins were sampled. Repositioning the point frame when sampling $52^{\circ}$ angle pins also resulted in a considerable amount of inadvertent trampling outside the plot because the user was required to stand on all 4 sides of the plot while positioning the frame to sample in all 4 cardinal directions. Repositioning of the point frame for repeated sampling of $90^{\circ}$ angle pins could 
be done while standing on one side of the plot thus minimizing trampling. Trampling outside the plot may eventually influence the LAI within the plot reducing the comparability of temporally-repeated LAI measurements. Furthermore, the longer pin path lengths of inclined pins resulted in noticeably more time spent waiting for pin vibrations to dampen than when $90^{\circ}$ angle pins were used. While pin droop was not a problem when using $90^{\circ}$ angle pins, it was a problem that had to be noted and corrected when using inclined pins. Given their practical benefits in the field, using $90^{\circ}$ angle pins may provide a better compromise between practicality, efficiency, and accuracy than using $52^{\circ}$ angle pins in sagebrush communities.

\section{Literature Cited}

Barclay, H. 2000. Assessing bias from boles in calculating leaf area index in immature Douglas-fir with the LI-COR canopy analyzer. Agr. and Forest Meteor. 100:255-260.

Beerling, D.J. and J.C. Fry. 1990. A comparison of the accuracy, variability, and speed of five different methods for estimating leaf area. Annals Bot. 65:438-488.
Bonham, C.D. 1989. Measurements for terrestrial vegetation. John Wiley and Sons, New York N.Y.

Cooley, K.R., C.L. Hanson, and C.W. Johnson. 1988. Precipitation erosivity index estimates in cold climates. Trans. ASAE 31:1445-1450.

Goodall, D.W. 1952. Some considerations in the use of point quadrats for analysis of vegetation. Aust. J. Sci. Res. Ser. B. 5:1-41.

Greig-Smith, P. 1983. Quantitative plant ecology, $3^{\text {rd }}$ ed. Univ. California Press, Berkley, Calif.

Hanson, C.L., R.P. Morris, R.L. Engleman, D.L. Coon, and C.W. Johnson. 1980. Spatial and seasonal precipitation distribution in southwest Idaho. USDA-ARS Reviews and Manuals, ARM-W-13.

Lapitan, R.L. and W.J. Parton. 1996. Seasonal variabilities in the distribution of the microclimatic factors and evapotranspiration in a shortgrass steppe. Agr. and Forest Meteor. 79:113-130.

Philip, J.R. 1965. The distribution of foliage density with foliage angle estimated from inclined point quadrat observations. Aust. J. Bot. 13:357-366.

Ramsey, F.L. and D.W. Schafer. 1997. The statistical sleuth: a course in methods of data analysis. Duxbury Press. Belmont, Calif.

SAS. 1988. SAS/STAT user's guide. Version 6.03. SAS Institute Inc. Cary, N.C.
Spaeth, K.E., J. Duft, and F.B. Pierson. 2000. Flora of the Reynolds Creek Experimental Watershed. USDA-ARS, NWRC 00-1, February 2000. Northwest Watershed Research Center, Boise, Ida.

Stephenson, G.R. 1977. Soil-geology-vegetation inventories for Reynolds Creek Watershed. Univ. Idaho Agr. Exp. Sta. Misc. Series No. 42. Moscow, Ida.

Warren Wilson, J. 1959. Analysis of the distribution of foliage in grassland, p. 51-61. In: Measurement of grassland productivity. Academic Press, Inc., New York, N.Y.

Warren Wilson, J. 1960. Inclined point quadrats. New Phytol. 59:1-8.

Warren Wilson, J. 1963. Estimation of foliage denseness and foliage angle by inclined point quadrats. Aust. J. Bot. 11:95-105.

Welles, J.M. and J.M. Norman. 1991. Instrument for indirect measurement of canopy architecture. Agron. J. 83:818-825. 